\title{
RULE-OF-LAW E A TEORIA DA IMPREVISÃO EM INVESTIMENTOS ESTRANGEIROS DIRETOS: O CASO CMS GAS TRANSMISSION COMPANY VS. REPÚBLICA ARGENTINA
}

\author{
RULE-OF-LAW AND THE THEORY OF UNPREDICTABLITY IN \\ FOREIGN DIRECT INVESTMENT: THE CMS GAS TRANSMISSION \\ COMPANY VS. ARGENTINE REPUBLIC CASE
}

Fernando Pedro Meinero*

\begin{abstract}
RESUMO: O presente trabalho aborda a aplicação da teoria da imprevisão no caso CMS Gas Transmission Company vs. República Argentina, julgado pelo Centro Internacional de Resolução de Diferenças em matéria de Investimentos. Apresenta as características do modelo de desenvolvimento implementado nos anos 1990 nos países latino-americanos, tendo a rule-oflaw como paradigma, materializada através de "boas práticas" institucionais, pela geração de clima de confiança para atrair os investidores externos. A crise econômica que atravessou o país dez anos depois provocou uma ruptura nesse clima. Busca-se analisar o instituto da teoria da imprevisão, para determinar se cabia a sua aplicação no caso em exame, de forma a justificar a mudança nas regras do jogo. Aborda a questão desde a perspectiva do direito internacional e o direito interno argentino.
\end{abstract}

PALAVRAS-CHAVE: Argentina. Investimentos. Rule-of-law. Teoria da imprevisão.

\begin{abstract}
This paper discusses the application of the theory of unpredictability in the case CMS Gas Transmission Company vs. Argentina, settled by the International Centre for Settlement of Investment Disputes. Analyzes the characteristics of the development model implemented in the 90's in the Latin America, and the rule-of-law as a paradigm, materialized by the institutional "best practices", to generate confidence to attract foreign investors. The economic crisis suffered by the country ten years later caused a break in this environment. Seeks to evaluate the institution of the theory of unpredictability, to determine it applicability in the case under examination, in order to justify a change in the rules of the game. Addresses the issue from the perspective of international law and domestic Argentinian law.
\end{abstract}

KEYWORDS: Argentina. Investments. Rule-of-law. Theory of unpredictability.

* Graduação em Direito pela Universidad Nacional del Litoral (2003), com Revalidação do Título pela Universidade Federal de Pelotas (2011), e Mestrado em Integração Latino-americana pela Universidade Federal de Santa Maria (2005). Doutorado em andamento no Programa de Pós-graduação em Direito da Universidade Federal do Rio Grande do Sul. É professor titular da Faculdade da Serra Gaúcha nos cursos de Direito e Administração de Empresas. E-mail: fernando.meinero@fsg.br. 
O presente trabalho se relaciona com a ideia de rule-of-law e com um instituto que rompe com a intangibilidade dos contratos perante situações de desequilíbrio econômico. $\mathrm{O}$ desequilíbrio contratual foi neste caso um dos efeitos das medidas adotadas em decorrência de uma crise econômica, política e social como a que vivenciou a Argentina a inícios da década passada. Ela deu-se a partir do esgotamento do modelo neoliberal, proposto pela mesma doutrina que entendeu que o principal papel do Estado era de garantir a proteção da propriedade privada e a estabilidade dos contratos, em que o mercado torna-se o principal motor do desenvolvimento (TRUBEK, 2006, p. 2).

As políticas de desenvolvimento impulsionadas pelos países latinoamericanos durante os anos 1990 tinham como característica o abandono do Estado enquanto protagonista na economia. No caso da Argentina, dentre as principais medidas se encontraria uma audaciosa reforma monetária - através da fixação de uma paridade entre o peso argentino e o dólar estadunidense, com vistas a dar estabilidade ao sistema e eliminar o processo de hiperinflação ${ }^{1}$ - bem como uma profunda reestruturação do Estado com vistas a diminuir o déficit nas contas públicas. A ineficiente gestão dos anos anteriores seria substituída pela iniciativa privada, através da atração de investimentos estrangeiros a diversos setores da economia, dentre eles o setor dos serviços públicos ${ }^{2}$.

$\mathrm{O}$ investimento estrangeiro foi prioridade para Argentina nesses tempos, e o direito devia criar o "clima propício" para o desembarque do capital externo. Desse modo, o setor do transporte de gás foi um dos principais setores do programa de privatizações, através de contratos de concessão que garantiam aos investidores estrangeiros diversas vantagens, dentre elas mecanismos de estabilização monetária para seus réditos.

Na Argentina de finais dos anos 1990, deflagrou-se uma série crise econômica, com altas taxas de desemprego e recessão (CORTES CONDE, 2003, p. 762-767). O consumo retraído afetou o setor de serviços e a crise motivou uma série de medidas, inicialmente aplicada a setores específicos, a exemplo do gás, e posteriormente, ao agudizar-se a crise, de forma mais genérica, no contexto das graves convulsões políticas, econômicas e sociais vivenciadas a finais de 2001 e

1 Trata-se da Lei 23.928/91, sobre conversibilidade monetária, e do Decreto 2128/91, que fixava a paridade do peso ao dólar. Em 1989, a inflação superou o $5600 \%$ anual. No mês de julho de 1989, o nível de inflação superou 200\% mensal. Entre julho de 1989 e dezembro de 1990, houve um nível de inflação superior aos $22000 \%$ (CASTRO, 2001, p. 2).

2 Oportunidade em que foi sancionada a Lei 23.969/89, sobre Reforma do Estado. 
começo de 2002 (BLANCO, 2005, p. 642). Essas medidas provocaram a reclamação de várias privatizadas, dentre as que se encontra a CMS Gas Transmission Company (CMS), que, em 12 de maio de 2005, ativou o sistema do Centro Internacional de Arbitragem para Disputas em matéria de Investimentos - CIRDI, órgão pertencente à estrutura do Banco Mundial, pelo desrespeito do marco normativo do investimento por parte da Argentina ao adotar tais medidas.

Esse tribunal arbitral, ao analisar as alegações do país sulino, observou a aplicabilidade de excludentes de responsabilidade, dentre as que se encontra o estado de necessidade e a teoria da imprevisão. Mas havendo-se dado largas explicações para rejeitar o primeiro, o mesmo não aconteceu com o segundo instituto, do qual fez uma parca referência ao desestimá-lo. Por isso cabe analisar, nesta oportunidade, a sua aplicabilidade ao caso, bem como aos contratos de investimentos de um modo geral. Ao tratar-se de um mecanismo que rompe com a intangibilidade dos contratos, ele deve ser motivo de especial reflexão quando aplicado aos contratos internacionais de investimento, por se tratarem de contratos de longa duração e sujeitos a mudanças no cenário econômico.

Pretende-se descobrir quais os parâmetros que o direito interno e internacional estabelece para a aplicabilidade da teoria do ponto de vista geral e, em particular, nos contratos de investimento, para entender se o princípio rebus sic stantibus, base da teoria da imprevisão, deveria ter sido admitido no caso.

Para esse propósito, será necessário observar que a relação de investidor estrangeiro-Estado se apresenta como complexa, na qual uma das partes, privada, exige segurança e estabilidade contratual em prol da busca de um interesse particular, precipuamente retorno financeiro, enquanto a outra se erige como uma figura pública, que tem como premissa básica o de garantir o bem-estar da população de um modo geral, e não apenas de uma determinada empresa ou grupo econômico, quer seja nacional quer seja estrangeiro. Levado ao campo estritamente jurídico, surgem dificuldades de enquadramento da relação. O Estado oferecerá ao investidor estrangeiro condições atrativas para apostar no país. Mas, diante do conflito, o Estado pretenderá enxergá-lo em condições de igualdade ao investidor nacional, sendo sujeito aos mesmos atos por parte da autoridade. A complexidade aumenta quando se inclui a figura do Estado exportador de capitais, com interesse no tratamento de seus investidores alhures.

A teoria da imprevisão representa um desafio ao pacta sunt servanda, princípio clássico dos contratos, e justifica que as partes possam adotar medidas para reequilibrar a relação quando eventos não levados em conta originalmente possam vir provocar uma ruptura desse equilíbrio, tornando para uma das partes 
a sua prestação excessivamente onerosa. A garantia de cumprimento dos contratos como uma das expressões dessa rule-of-law deve ser compatibilizada com este instituto há muito tempo presente dentro do âmbito privado. Resta saber então se ele resulta invocável aos contratos de investimento, que se sustentam no direito interno, mas também no direito internacional.

Uma forma bastante simples de explicar o que são os tratados internacionais consiste em dizer que são como contratos internacionais, com a diferença de que quem o celebra é o Estado. Contudo, observa-se que essa distinção, enquanto ferramenta didática tem uma função um pouco limitada (ORREGO VICUÑ A, 2005, p. 18). Não apenas organizações internacionais ou entes federados podem celebrar tratados (REZEK, 2006, p. 18 e 235), mas, sobretudo, porque o Estado celebra contratos com pessoas estrangeiras.

O fenômeno da internacionalização dos contratos não é um fenômeno novo. Toda vez que o comércio ultrapassa as fronteiras de um país ocorre um processo de internacionalização. Mas, de operações internacionais simples, passou-se a estruturas negociais mais complexas (ORREGO VICUÑNA, 2005, p. 20).

Um dos aportes mais representativos dessa internacionalização dos contratos tem sido a dos tribunais arbitrais que, ao mesmo tempo que resolvem disputas comerciais, são constituídos em órgãos que apresentam uma maior independência do que as jurisdições nacionais. Deste modo, fazem valer princípios que representam consensos globais, nem sempre de acordo com as necessidades particulares de cada Estado. Nesse sentido, a ordem pública que governa as transações internacionais não é uma ordem pública doméstica, mas uma ordem pública globalizada.

A relação estabelecida num contrato de Estado para a recepção do investimento estrangeiro resume esse movimento. A dificuldade de disciplinálo sob o manto da ordem internacional ou doméstica dá lugar à discussão sobre qual deve ser o caminho para a resolução da disputa entre as partes, bem como determinar qual o direito aplicável à relação.

Deve se observar que na relação existem, no mínimo, três atores com interesses diferenciados: o investidor estrangeiro, o Estado importador de capital e Estado exportador de capital. Na maioria dos contratos de investimento, os primeiros serão grandes grupos econômicos constituídos no terceiro país, normalmente um país desenvolvido. Os segundos serão normalmente países em desenvolvimento. 
O Estado que importa investimento é um Estado a quem o direito internacional reconheceu como detentor de soberania econômica sobre seus recursos naturais, e essa soberania se traduz não apenas o direito de legislar sobre assuntos econômicos, mas o poder de tornar-se um protagonista econômico e celebrar contratos para que privados estrangeiros explorem serviços públicos ou recursos. A soberania econômica, assim entendida, confere o direito de nacionalizar investimentos, bem como entrar em relações com contratantes estrangeiros (STERN, 2003, p. 16). Os Estados importadores de investimento enxergam-se como administradores públicos e reguladores da atividade, pairando sobre esses contratos o perigo do descumprimento por parte deste justificado em razões de ordem pública econômica, sobretudo quando um novo governo assume o poder.

A respeito do tratamento dado ao investidor, os países receptores do investimento pretendem submeter a todos, que seja nacional, quer seja estrangeiro, a padrões de tratamento nacional. Desse modo, o investidor estrangeiro não teria por que receber um tratamento mais favorável. O princípio do tratamento nacional ao estrangeiro e a sua propriedade é um princípio geral do Direito Internacional Público, baseado na equidade e não discriminação. Dessa forma, os estrangeiros admitidos no território devem submeter-se aos mesmos regulamentos relativos à segurança pública, bem como observar a noção de ordem pública interna e internacional do Estado hospedeiro. Contudo, o tratamento nacional é o mais importante princípio nos acordos internacionais de investimento e, ao mesmo tempo, o mais difícil de ser implementado, por estar frequentemente sujeito a exceções e não poder seu conteúdo ser definido a priori, de forma absoluta (SCHLEE, 2005, p. 84 e 90).

Por outro lado, o investidor estrangeiro reclamará no processo de negociação, garantias de estabilidade dos contratos, rentabilidade, tratamento justo e equitativo, liberdade para expatriar os lucros obtidos, enfim, padrões de segurança jurídica. É o que se conhece como tratamento em um international minimum standard (SCHLEE, 2005, p. 83). No contexto latino-americano, como se verá, seria a concretização de parte das "boas práticas" indicadas pela rule-of-law.

Participando dessa relação entre Estado importador de capital e investidor encontra-se o Estado exportador ao qual pertence o investidor, isto é, o exportador do capital. É princípio do Direito Internacional Público a potestade deste último em exercer a chamada proteção diplomática (REZEK, 2006, p. 276). Através dela, o Estado exportador de capital pode levar a tribunais internacionais a defesa de 
um nacional seu cujo direito tenha sido violado por outro Estado. Desse modo, o descumprimento do contrato de investimento passaria a ser resolver entre Estados soberanos ${ }^{3}$.

Essa relação entre países em desenvolvimento e países desenvolvidos procuraria o equilíbrio em mecanismos intermediários, que se traduziram na utilização da arbitragem internacional, principalmente o sistema oferecido pelo Centro Internacional de Resolução de Disputas em matéria de Investimentos CIRDI, na órbita do Banco Mundial (ICSID, 2013).

Em segundo lugar, estabelecer qual seria o direito aplicável nessa relação jurídica entre investidor e Estado estrangeiro. A questão que surge desses instrumentos é se o descumprimento a que este possa dar lugar pode:

- ser considerado uma violação ao Direito Internacional e, portanto, sujeito a parâmetros e juízos próprios de um sistema que o coloca a par de outros atores, no mesmo patamar que o investidor e, sobretudo, do Estado estrangeiro ao qual esse investidor pertence; ou

- entender que uma violação desses contratos constitui uma questão doméstica que se justifica em último caso pelo exercício de um poder de soberania sobre a atividade econômica no seu território e o decorrente poder de administração. Nesta perspectiva, o investidor estrangeiro, por isso, encontra-se numa posição de subordinação, pois sua relação é governada pelo contrato administrativo (LALIVE, 1969, p. 101).

Os investimentos continuam a ser realizados através de contratos com o Estado, mas nas últimas décadas o fluxo dos investimentos na direção NorteSul, demandou mecanismos que permitissem conciliar a demanda por segurança jurídica na aplicação do direito. Um dos reflexos do paradigma de novo papel do Estado na economia dos países em desenvolvimento foi a busca pela celebração dos chamados Tratados Bilaterais de Investimento - TBIs. Trata-se de acordos internacionais firmados por dois Estados por meio dos quais se estabelecem direitos e deveres recíprocos a ambos, com a particularidade que os maiores beneficiários de tais tratados são os investidores (FONSECA, 2008, p. 57). Hoje, existem mais de $2000 \mathrm{TBIs}$ que buscam proteger os investimentos estrangeiros, junto com algumas convenções multilaterais e tratados de livre comércio (ORREGO VICUÑ̃, 2005 , p. 25).

3 Para evitar os efeitos da proteção diplomática, os Estados receptores de investimento utilizavam a denominada "cláusula Calvo". Através dela, o investidor renunciava, pelo contrato, a solicitar proteção diplomática do seu país de origem, devendo submeter-se aos tribunais locais que provavelmente faria prevalecer o direito interno, com padrões de tratamento nacional afastado do mínimo internacional mencionado. Os países desenvolvidos e em desenvolvimento se embarcaram numa discussão, alegando os primeiros a nulidade da cláusula por não ser a proteção diplomática uma prerrogativa do indivíduo, mas do Estado que a exerce (REZEK, 2006, p. 285). 
Todos esses partilham a característica de que, apesar de serem tratados entre Estados, permitem aos particulares amparar-se nos seus preceitos tanto no que refere a padrões de tratamento como no referente à eleição de foro, incluindo especialmente a arbitragem internacional, como um meio de evitar a parcialidade das cortes locais. Esses tratados, ainda, poderiam ser invocados através das cláusulas "cláusulas guarda-chuva", através da qual, qualquer violação do contrato é considerada automaticamente uma violação do tratado (ORREGO VICUÑNA, 2005, p. 28).

O cenário latino-americano constitui um excelente campo para o estudo das complexas relações entre investidores estrangeiros e Estado. Em definitiva, foram esses países que se tornaram grande destino dos investimentos estrangeiros diretos. Para uma acabada compreensão do contexto, resulta indispensável ao modelo de desenvolvimento que os países exportadores de capital entendiam como "boas práticas", dentre as quais se encontrava a promoção da importação do capital.

\section{PARADIGMA DO RULE-OF-LAW E NOVO PAPEL DO ESTADO}

Ao longo dos anos 1960 e inicio dos 1970, acadêmicos e formuladores de políticas públicas se dedicaram a estudar quais seriam os atributos jurídicoinstitucionais que conformavam o funcionamento dos mercados e sociedades de países da periferia. Eles percebiam que o desenvolvimento que estes sofriam era produto do atraso que tais atributos apresentavam e observavam uma inadequada resposta desses sistemas ao ambiente de negócios, por contar com ineficientes estatutos regulatórios. Já nos anos 1980, o papel do Direito ocupou um espaço central na discussão sobre o Desenvolvimento. Precisamente, a discussão da relação entre Direito e Desenvolvimento se daria de uma forma bastante particular, influenciada por ideias econômicas neoliberais, que potencializavam o papel dos mercados no crescimento econômico. Por isso, o direito seria concebido como a base das relações de mercado e como freio à intervenção do Estado (TRUBEK; SANTOS, 2006, p. 2). Esse entendimento em torno ao ambiente institucional e da sua relevância para a promoção dos mercados tem consolidado um novo paradigma no campo da economia do desenvolvimento. Trata-se do rule-of-law, um conjunto definido de concepções econômicas e estratégias políticas para a promoção do crescimento e a modernização econômica das nações (TRUBEK; SANTOS, 2006, p. 2). Desse modo, a estratégia do rule-of-law na relação de direito e desenvolvimento se traduz em 
um determinado modelo de desenvolvimento econômico, que é baseado em transações privadas, mediadas pelas garantias jurídicas de proteção à propriedade privada aos termos contratuais, e é vinculado, ainda, a um viés definido de políticas públicas, em que prevalece uma relação de Estado/economia comprometida com a preservação dos mercados como espaços de alocação dos recursos.

Deste modo, o rule-of-law se constituiria em um conceito chave para permitir a garantia, previsibilidade e calculabilidade das transações privadas. $O$ fato de contar com regras claras, proteção adequada da propriedade privada, certeza no cumprimento dos ajustes contratuais e a confiança no funcionamento célere e independente do Poder Judiciário passaram a ser os pressupostos necessários para esses atributos jurídico-institucionais.

A rule-of-law seria essencial para a promoção das chamadas "boas práticas" nos países em desenvolvimento. Tais estudos serviriam de inspiração teórica para que, nos anos 1990, e legitimando-se através de organizações internacionais, se recomendasse um "pacote de instituições corretas", transplantáveis de um país a outro como caminho ao desenvolvimento (SCHAPIRO, 2011, p. 124). Tais instituições corretas seriam as que propiciassem um ambiente adequado para os negócios.

Nesta passagem de Milhaupt e Pistor, trazidos por Schapiro, se percebe-se a relação do conceito com o ambiente esperado pelos investidores nesse modelo neoliberal:

\footnotetext{
Segundo a visão prevalecente, o direito promove a atividade econômica (exclusivamente) por meio da proteção dos direitos da propriedade. Um sistema jurídico que atribui e protege claramente os direitos da propriedade (o rule-of-law) precede o desenvolvimento econômico e constitui uma condição prévia para o sucesso econômico. Uma vez que esse sistema está em vigor, constitui-se uma dotação institucional fixa e politicamente neutra - uma função rígida para a atividade econômica. As características formais do sistema jurídico - em particular, se se trata do common law ou do civil law - determinam quão bem eles garantem a proteção dos direitos de propriedade (especialmente o direito dos investidores). A qualidade da proteção dos direitos de propriedade, por sua vez, determina os resultados econômicos (SCHAPIRO, 2011, p. 128).
}

O Banco Mundial teve papel fundamental na difusão dessa fórmula de rule-of-law para os países latino-americanos, a partir de uma mudança no seu papel tradicional, antes encarregado de financiar obras de infraestrutura e agora alterando o destino dos seus desembolsos. Desse modo, o alvo preferido dos recursos passou a consistir em programas de requalificação institucional, 
promovendo reformas institucionais sob o dogma "one size fits all", isto é, que os modelos preestabelecidos poderiam ser importados de países desenvolvidos onde teriam tido sucesso, para países em desenvolvimento e menos desenvolvidos, sem dar devida atenção às singularidades de cada país, de cada economia, de cada realidade social (SHAPIRO; TRUBEK, 2012, p. 40).

Do ponto de vista econômico, a série de reformas necessárias para o bom funcionamento do mercado enquanto concebido como impulsor do desenvolvimento tinham como norte ideológico o chamado Consenso de Washington, que encontrava na América Latina um ambiente propício para reformas radicais: dívida pública elevada; carga tributária proibitiva aos investimentos privados; e controles excessivos no câmbio, nas taxas de juros e nos investimentos estrangeiros; e participação excessiva do Estado nas atividades do mercado (SHAPIRO; TRUBEK, 2012, p. 35). Com isso, o principal alvo das reformas foram a diminuição do déficit fiscal, a redução da abrangência da abrangência reguladora do Estado e a melhoria do ambiente de negócios, através de mecanismos de proteção aos investidores, e alterações no funcionamento do poder judicial, considerado excessivamente moroso (SCHAPIRO, 2011, p. 131).

Por causa dessa agenda de reformas econômicas, as empresas estatais foram privatizadas, cabendo ao Estado apenas um papel regulatório, criando agências fiscalizadoras com base no modelo norte-americano. Na Argentina, em somente quatro anos (1990-1994) se privatizaram grande parte de YPF (petrolífera estatal); a empresa Gasdel Estado; as empresas estatais de geração, transporte e distribuição de energia elétrica; a telefônica estatal, Aerolíneas Argentinas; os estaleiros e as siderúrgicas e petroquímicas de propriedade estatal; a administração dos sistemas portuários; canais de rádio e TV (ABELES, 1999, p. 4).

Como apontado, nesse novo paradigma, o valor segurança jurídica tornouse o valor supremo a ser garantido pelos Estados receptores de investimento. $\mathrm{O}$ Estado devia garantir rentabilidade e tratamento propício a empresas que se dispunham a assumir o risco de investir nas jovens democracias latino-americanas.

A seguir, será apresentado o caso CMS Gas Transmission Company vs. República Argentina (CMS-ARG), resolvido pelo Tribunal Arbitral do CIRDI em 2005. Serão expostos brevemente os elementos fáticos do caso, acompanhado das principais alegações de ambas as partes e as observações do Tribunal Arbitral acerca da aplicação do estado de necessidade como possível excludente. Isso se faz necessário para apreciar, no próximo ponto, a aplicabilidade da teoria da imprevisão ao caso analisado. 
O caso CMS-ARG é um dos tantos $\operatorname{casos}^{4}$ em que o país foi levado ao CIRDI em virtude dos efeitos que a crise econômica de 2001-2002 teve sobre os contratos de investimento.

Ao privatizar-se a empresa Gas del Estado, constituiu-se uma sociedade argentina denominada Transportadora de Gas del Norte (TGN) que obteve licenças de transporte de gás na região norte e centro do país por um período de 35 anos (prorrogável por mais 10 anos, desde que cumpridas certas condições) e cujas ações, de propriedade do Estado, foram vendidas no mercado de capitais a investidores privados. Dentre os investidores encontrava-se a CMS Gas Tramission Company (CMS), de capitais estadunidenses, que comprou 25\% das ações de TGN, adquirindo em um segundo momento um pacote adicional de 4,42\%. No total, a CMS detinha 29,42\% das ações de TGN (BLANCO, 2005, p. 641).

O regime das tarifas estava previsto no marco regulatório específico, constituído pelas licenças e pelo próprio regime de privatização ${ }^{5}$. Segundo esse regime, as tarifas deviam ser calculadas em dólares americanos na data do faturamento, aplicando-se um procedimento de reajuste a cada seis meses, pelo Índice de Preços ao Produtor (IPP) norte-americano, além de mecanismos de estabilização (BLANCO, 2005, p. 642).

Nos últimos meses de 2001, teve lugar uma radicalização da crise que os derradeiros anos 1990 arrastavam, com uma considerável fuga de capitais acompanhada de boatos de uma possível desvalorização da moeda ${ }^{6}$. Já durante o governo de Eduardo Duhalde decretou-se uma Lei de Emergência Econômica $\mathbf{n}^{\circ} 25.561$ (ARGENTINA, 2013), que estabeleceu importantes modificações nos valores de depósitos, declarando o abandono da paridade peso-dólar, liberando o tipo de câmbio, agora valendo na base na oferta e da procura. Por outra parte, as tarifas dos serviços públicos, como as de gás, antes pautadas em dólares, se

4 Atualmente, a Argentina figura como demandada em 50 casos no CIADI, sendo a mais demandada desde a criação do Tribunal. A maioria deles levados pelas empresas que desembarcaram no país nos anos de Governo de Carlos Saúl Menem. A lista de casos pode ser consultada no site do CIADI (ICSID, 2013; FELDSTEIN DE CÁRDENAS, 2005, p. 589).

5 O marco regulatório estava determinado pela Lei 24.076/92 e o Decreto 1738/92.

6 Uma taxa de desocupação de $20 \%$, mal-estar social, e o chamado corralito financeiro foram o coquetel explosivo detonado em 21 de dezembro de 2001 com a saída do então Presidente Fernando de la Rua. Em poucos dias sucederam-se três presidentes. Um deles, Adolfo Rodriguez Saá, decretou a cessação de pago da dívida externa e o risco-país atingiu níveis estratosféricos. 
“pesificariam" ao tipo de câmbio UM DÓLAR - UM PESO, não sendo mais reajustadas como constava no contrato de concessão (BLANCO, 2005, p. 644).

As medidas do governo tiveram consequências catastróficas para a CMS. O valor das ações de TGN viu-se reduzida em 92\% e os seus ingressos diminuíram um $75 \%$. Ainda, a desvalorização afetou os custos de TGN parcialmente pagáveis em dólares, impedindo recorrer ao mercado financeiro internacional. A esses efeitos, alegou a CMS que a Lei de Emergência representou um subsídio direto ao consumo do gás em favor do consumidor que não se traduzia em um aumento de ingressos para a companhia, haja vista que se tratava de um congelamento de tarifas. Como consequência, a CMS deveu suspender projetos de investimento e expansão, dando lugar a recortes no fornecimento de gás, tanto no mercado interno como na exportação a países vizinhos (parágrafos 68 a 73 do Laudo Arbitral).

A CMS ativou o sistema de arbitragem do CIRDI em virtude dos danos provocados pela citada Lei de Emergência. Alegando seus danos, a firma manifestou que sua decisão de investir esteve fundada em compromissos e garantias que o governo argentino oferecia em especial a de rentabilidade por tarifas calculadas dólares, o sistema de reajuste baseado no IPP dos Estados Unidos.

No que respeita a seus fundamentos jurídicos, a CMS alegou que as medidas adotadas pelo governo violavam os compromissos assumidos perante investidores estrangeiros. Em particular, os compromissos diziam respeito à violação das cláusulas de licença que estabeleciam a manutenção do valor real das tarifas. Segundo a CMS tais cláusulas eram condições essenciais para o investimento e constituíam um direito adquirido (parágrafos 84 a 86 do Laudo Arbitral).

Sobre o marco regulatório internacional desse investimento, a CMS alegou violação do Tratado de Promoção e Proteção Recíproca de Investimentos entre EUA e Argentina de 15 de novembro de 1991 (ARGENTINA, 2013b). Em particular, alegaram por parte da Argentina a violação dos seguintes artigos do Tratado: art. IV: Expropriação ilegal e sem indenização; art. II (2) (a): Descumprimento de um dever de tratamento justo e equitativo; art. II (2) (b): Adoção de medidas arbitrárias e discriminatórias; art. II (2) (c): De um modo geral, descumpriu os compromissos assumidos em virtude do investimento (parágrafos 87 a 88 do Laudo Arbitral).

Como pretensão, a CMS reclamou o pagamento de 261,1 milhões de dólares em caráter de indenização mais atualização e honorários.

O Tribunal tratou do descumprimento dos compromissos assumidos com o investimento estrangeiro a partir da análise do direito ao cálculo da tarifa em dólares (parágrafos 127 a 138 do Laudo Arbitral), reajuste em virtude do 
IPP (parágrafos 139 a 144 do Laudo Arbitral) e aplicação dos mecanismos de estabilização (parágrafos 145 a 151 do Laudo Arbitral), considerando que a CMS tinha direito a tais mecanismos consagrados nos instrumentos jurídicos, tanto do marco regulatório como da própria licença. Nesse sentido, os termos eram claros e precisos. No que respeita à alegação acerca do direito da CMS a uma tarifa justa e razoável, o Tribunal considerou que o congelamento da tarifa e a alteração do tipo de câmbio provocaram um desaparecimento dos ingressos da companhia.

As justificativas apresentadas pela Argentina para as medidas adotadas tiveram por base tanto o direito interno argentino quanto o direito internacional. A principal defesa da Argentina - e que perpassa a maior parte do Laudo - estaria dada pela existência de um estado de necessidade, expressado num estado de emergência econômica. Segundo ela, a crise foi grave do ponto de vista social, econômico e político, pondo em risco o próprio Estado e, por isso, as medidas adotadas estariam amparadas pelo direito interno argentino, pelo internacional consuetudinário e pelo próprio tratado bilateral de investimentos.

Do ponto de vista do direito consuetudinário, a Argentina invocou o caso Gab íkvo-Nagymaros Project, da Corte Internacional de Justiça (ICJ, 1997). Ainda, invocou o art. 25 do Projeto de Artigos da Comissão de Direito Internacional das Nações Unidas sobre Responsabilidade Internacional dos Estados ${ }^{7}$. Segundo o Tribunal, a Argentina não preenchera as condições do art. 25 invocado, pois não comprovou que as medidas adotadas seriam o único modo para resolver o impasse (parágrafo 324 do Laudo Arbitral). Ainda, embora tenha reconhecido a existência de fatores exógenos, entendeu que estes não foram exclusivos causadores da crise (parágrafo 329 do Laudo Arbitral).

Relacionado ao estado de necessidade, invocou os arts. XI e IV (3) do Tratado Estados Unidos - Argentina, que dispõe sobre as chamadas "medidas não preclusas", como prerrogativas que o Estado hospedeiro se reserva de adotar para a "manutenção da ordem pública, o cumprimento de suas obrigações para a manutenção ou a restauração da paz ou segurança internacionais, ou a proteção de seus próprios interesses essenciais de segurança" (parágrafos 332 e

Art. 25. Estado de necessidade 1. Nenhum Estado pode invocar o estado de necessidade como causa de exclusão de ilicitude de um ato em desacordo com uma obrigação internacional daquele Estado, a menos que o ato: a) seja o único modo para o Estado preservar um interesse essencial contra um perigo grave e iminente; e b) não afete gravemente a um interesse essencial do Estado ou Estados em relação aos quais exista a obrigação, ou da comunidade internacional como um todo. 2 . Em nenhum caso pode o Estado invocar o estado de necessidade como causa de exclusão de ilicitude se: a) a obrigação internacional em questão exclui a possibilidade de invocar a necessidade, ou b) o Estado contribuiu para a ocorrência do estado de necessidade (UNITED NATIONS, 2001). 
333 do Laudo Arbitral). As medidas não preclusas autorizadas pelo Tratado serão motivo de especial atenção do Tribunal, com motivo do que deve ser considerado "interesses essenciais de segurança", pois a juízo da Argentina caberia somente a ela preencher o seu conteúdo. Contudo o Tribunal entenderá que as proporções da crise não foram capazes de afastar a responsabilidade da Argentina, pois, apesar de aguda, não atingiu proporções catastróficas.

Embora a principal excludente tratada tenha sido o estado de necessidade, o Tribunal teve a oportunidade de manifestar-se sobre a aplicabilidade da teoria da imprevisão ao caso, excluindo-a. Cabe observar, em apartado próprio, quais foram as observações do Tribunal, e os apontamentos da doutrina e da jurisprudência acerca da sua aplicabilidade em contratos de investimento.

\section{PACTA SUNT SERVANDA E A TEORIA DA IMPREVISÃO}

A autonomia da vontade contratual considera ao indivíduo como uma pessoa moral com capacidade para fazer escolhas. A liberdade comporta autorresponsabilidade, porque "as partes são escravas daquilo que falam" (LORENZETTI, 2005, p. 51). Deste modo, essa liberdade, que serve como fundamento para a força obrigatória dos contratos, tem inspiração filosófica kantiana (ARAUJO, 2004, p. 43). Se o homem essencialmente livre, não pode obrigar-se senão através da sua vontade, e é essa vontade que cria os efeitos do contrato, de modo que os efeitos jurídicos não existem senão por tem sido queridos e da forma como foram queridos. Nessa mesma ideia, o contrato não pode ser injusto se foi livremente consentido (REZZONICO, 1999, p. 187). Esse princípio será consagrado tanto na ordem interna dos Estados quanto no âmbito internacional para aquelas normas que governam as relações entre privados (o Direito Internacional Privado) e entre Estados (Direito Internacional Público).

No âmbito interno, o art. 1.197 do Código Civil argentino dispõe que "As convenções são feitas em contratos formam para as partes uma regra à qual devem se submeter como se fosse a própria lei". ${ }^{8}$

O pacta sunt servanda como princípio também está consagrado como fundamento para o efeito obrigatório dos tratados internacionais, que, ao invés de assentar-se na vontade individual da pessoa humana, tem apoio na soberania dos Estados. Assim, a regra constitui o verdadeiro fundamento do Direito Internacional Público, pelo exercício de soberania que representa a celebração dos tratados internacionais. Nesse sentido, sustenta Verdross:

\footnotetext{
8 "Las convenciones hechas en los contratos forman para las partes una regla a la cual deben someterse como a la ley misma" (tradução nossa) (ARGENTINA, 2013c).
} 
não é a vontade como tal, quer a de um Estado, quer a comum de todos ou de vários Estados que faz nascer o direito internacional; a força obrigatória deste decorre da regra objetiva pacta sunt servanda, que impõe a estes o respeito da palavra dada (VERDROSS, 1927, p. 288).

Essa ideia foi definitivamente consagrada na Convenção de Viena sobre o Direito dos Tratados, no seu art. 26, deixando expresso que "todo tratado em vigor obriga as partes e deve ser cumprido por elas de boa-fé"

Do ponto de vista das relações contratuais internacionais, o princípio do pacta sunt servanda também encontra consagração nos Princípios da UNIDROIT 2010 aplicáveis aos contratos internacionais:

Artigo 1.3 Um contrato validamente celebrado é vinculatório entre as partes. Ele somente pode ser modificado ou extinto em conformidade com o disposto em suas próprias cláusulas, ou pelo comum acordo das partes, ou ainda segundo previsão diversa contida nos presentes Princípios (UNIDROIT, 2010).

Nos âmbitos mencionados, o princípio pacta sunt servanda está relacionado com a ideia de segurança jurídica. O princípio aponta à previsibilidade, à certeza, a saber quais as condições às quais os contratantes se atêm, que segundo Lorenzetti tem duas faces: 1. Que a contraparte cumpra a palavra empenhada, que nos aspecto jurídico é o efeito vinculante do contrato [...]; 2. Que não mudem as regras gerais que regulamentam o pactuado. Por isso, uma mudança de regras afeta a previsibilidade, pois o contrato é um meio através do qual as partes projetam o seu futuro, seus recursos, suas escolhas e inclusive os seus riscos (LORENZETTI, 2005 , p. 51). Quando as partes fecharam o acordo de vontade, deram nascimento no mundo jurídico a um ato de previsão, que se realiza em prol de ter segurança. Desse modo, uma ou ambas as partes querem influenciar sobre o futuro, amarrando-o com a realidade presente tal e como é conhecida, ou com suas mudanças futuras previsíveis (REZZONICO, 1999, p. 413).

Quando o ambiente econômico sofre um transtorno generalizado, agudo e imprevisto, resultaria ilógico pretender que o contrato não sofra essas consequências e que a justiça permaneça alheia a essa realidade. Por outro lado, em termos absolutos, se a autonomia da vontade está ligada ao dogma da palavra empenhada, não deveria autorizar que a superveniência de eventos causadores de um desequilíbrio na economia do contrato permita o reequilíbrio das posições

9 Esse artigo vem acompanhado de outra manifestação mais prática do pacta sunt servanda. Com efeito, o artigo 27 já dispõe que "não poderá invocar-se disposição de direito interno para justificar o descumprimento por de tratados internacionais" (BRASIL, 2013). 
contratuais, nem a liberação de um dos contraentes dos prejuízos suportados. Desse modo, a intangibilidade absoluta do contrato vedaria a intervenção do juiz ou do árbitro para tal fim, pois, de não se cumprir a palavra empenhada, a segurança jurídica estaria ameaçada. Eis o desafio que apresenta a teoria da imprevisão ao pacta sunt servanda.

A teoria da imprevisão baseia-se no brocardo "rebus sic stantibus" de velha estirpe no direito romano, que significa que os contratos são obrigatórios "desde que assim se mantenham as condições". Deste modo, uma mudança de circunstâncias que tornasse excessivamente oneroso para uma das partes o cumprimento da obrigação, autorizar-se-ia um reequilíbrio (ZIMMERMAN, 1995, p. 579).

Esta teoria que nasceu no direito civil, foi abandonada nos séculos XVIII e XIX, haja vista a concepção de contrato liberal imperante (JIMENEZ GIL, 2010, p. 17-49). As partes, ao serem livres para contratar, deveriam suportar individualmente o alea contratual nos contratos de trato sucessivo, ou seja, aqueles que prolongam sua vigência e seus efeitos em um período mais ou menos longo após sua celebração. Desse modo, mesmo na presença de eventos que venham modificar as condições, tornando-as de tal forma que não poderiam ter sido advertidas, ficariam amparadas pela assunção livre e voluntária das regras do jogo, com riscos previsíveis e imprevisíveis. O cenário mudaria com o pós-guerra (MAGOJA, 2012, p. 233), consagrando-se a "rebus sic stantibus" no âmbito jurisprudencial, para depois ser recepcionado em alguns textos legislativos ${ }^{10}$.

Neste sentido, destaca Orgaz as mudanças que o mundo vivencia e que servem de adubado terreno para aplicação da teoria:

As condições da vida atual, entretanto, variaram que tal modo que, se o mundo anterior à guerra de 1914 pôde ser chamado com razão 'o mundo da segurança', este de agora pode designar-se, com igual fundamento, 'o mundo da insegurança': o estado constante de comoção bélica que agita aos povos e homens, com suas repercussões concretas no campo da economia (alta e baixa súbita de valores, inflação, desvalorização das moedas, intervenção do Estado nas atividades privadas, etc.), torna realmente imprevisíveis a maior parte dos acontecimentos que surgem breve tempo transtornando os cálculos mais prudentes, os planos melhor concebidos e organizados (ORGAZ, 1950, p. 691).

A complexidade da relação de investimento, por estar pautada por um contrato entre investidor e Estado e, ao mesmo tempo, apoiar-se em relações bilaterais com o Estado exportador do capital, motiva o análise da teoria desde o direito doméstico e internacional. Por isso far-se-á referência à receptividade da teoria no direito argentino e no direito internacional.

${ }^{10}$ Vide ponto 6 infra referente ao caso Gaz de Bordeaux. 
A maioria dos países latino-americanos recepcionou, nas legislações internas, disposições expressas tanto do pacta sunt servanda quanto da teoria da imprevisão. ${ }^{11}$ No caso da Argentina, esta última não tinha sido prevista no Código Civil de 1871, de forte inspiração liberal ${ }^{12}$. A introdução se daria no art. 1198 do Código Civil, incorporado pela lei 17.711/68:

Art. 1198. [...] Nos contratos bilaterais comutativos e nos unilaterais onerosos e comutativos de execução diferida ou continuada, se a prestação de uma das partes se tornasse muito onerosa, por acontecimentos extraordinários e imprevisíveis, a parte prejudicada pode pedir a resolução do contrato. O mesmo princípio se aplica aos contratos aleatórios quando dificuldade ocorra por razões estranhas ao próprio risco do contrato (ARGENTINA, 2013c).

Da análise da norma se observam alguns elementos que precisam dar-se para que ela possa solicitar a resolução do contrato que, naturalmente, trata-se daquele de duração prolongada. Em primeiro lugar, que o descumprimento da obrigação tenha sido ocasionado por um evento imprevisível, inevitável, estranho ao devedor e que sobreveio à obrigação. Em segundo lugar, que o devedor não tenha incorrido em mora nem culpa determinantes da maior onerosidade. Por último, que o evento fortuito tenha provocado uma excessiva onerosidade no cumprimento da obrigação (ALTERINI; AMEAL; LOPEZ CABANA, 2003, p. 387).

A teoria da imprevisão foi bastante útil para os efeitos que o chamado "Rodrigazo" provocou na economia argentina. ${ }^{13}$ Uma série de medidas, dentre as

11 No caso dos países do Cone Sul, o Código Civil brasileiro consagrou a teoria nos arts. 478/480. O Uruguai não possui uma norma expressa, mas se infere dos arts. 1283, 1284 e 1291 do Código Civil. O Paraguai conta com o art. 672 do Código Civil, similar ao art. 1198 argentino.

12 Apesar de não prevista, vinha sendo aplicada na jurisprudência, nos seguintes casos: CNFed, Sala Civil y Com., “Oks Hnos. y Cía., S.A. c/ Gobierno Municipal”, julgado em 25 ago 1965. El Derecho, Tomo 14, p. 170-177; CNCiv., sala C, "Cabal, Justo I. c/ Madero, Miguel y otro", julgado em 18 nov 1953 , La Ley, Tomo 75, p. 255-263; CNCiv., sala D, "Sola, Félix c/Colonias y Estancias El Rodeo S.A.", julgado em 26 maio 1964, El Derecho, Tomo 10, p. 726-732; CNCiv., sala F, “Pantaleón, Horacio J. c/ Carnerero, Ángel V.", julgado em 2 abr. 1965, El Derecho, Tomo 12, p. 89-97; CNCiv., sala D, “Reyes, Juan C., suc. c/ Bronstein, José V. y otros", julgado em 30 dec. 1965, El Derecho, Tomo 14, págs. 100-104; CNCiv., sala E, "La Hidrófila Argentina, S.A.C.I. c/ Municipalidad de la Capital", julgado em 01 mar. 1966, El Derecho, Tomo 14, p. 160-167.

${ }^{13}$ O denominado "Rodrigazo" (assim denominado em alusão a Celestino Rodrigo, ministro de Economia de Maria Isabel Martinez de Perón) foi um mega-ajuste ocorrido no ano de 1975. Desvalorizou a moeda em mais de 100\% e aumentou as tarifas entre o 170\% e 200\% (AMATO, 2013). 
que se encontrava uma desvalorização da moeda nacional, provocou a ruptura de diversos contratos, tanto para os celebrados em moeda nacional, quanto os ajustados em moeda estrangeira. A jurisprudência aplicou o supracitado artigo, por entender que circunstâncias extraordinárias e imprevisíveis também podem ser de caráter econômico. Neste sentido, foi decidido que:

5. Para a qualificação de imprevisão do encargo superveniente para uma das prestações do contrato, não é necessário ater-se somente aos casos de guerra ou catástrofes similares, pois é extraordinário e não possível de prever um ato de política econômica governamental que desencaixe com violência e estrepitosamente a previsível e corrente depreciação monetária.

10. A cláusula sobre invariabilidade de preços entra no campo da autonomia da vontade, mas somente compreende o previsível em matéria de preços; a alteração anormal excede o campo contratual e passa a integrar o terreno do heteronômico ${ }^{14}$.

Nos anos seguintes, a jurisprudência manteve-se constante ao longo dos anos e a doutrina a entendeu perfeitamente aplicável aos eventos dos anos 20012002 que motivaram o conflito apresentado neste ensaio (CORNET, 2002, p.77).

Inclusive, pois ela está reconhecida na própria Lei de Emergência Econômica antes citada, já prevendo a necessidade de negociação das compensações decorrentes da desvalorização da moeda:

2) as partes negociarão a reestruturação de suas obrigações recíprocas, procurando compartilhar de modo equitativo os efeitos da modificação da relação de mudança que resulte da aplicação do disposto no artigo $2^{\circ}$ da presente lei, durante um prazo não maior a CENTO E OITENTA (180) dias. Acordadas as novas condições, compensarse-ão as diferenças que eventualmente existam entre os pagamentos feitos e os valores definitivamente acordados; 3) de não mediar acordo entre as partes, as mesmas ficam facultadas para continuar com os procedimentos de mediação vigentes nas respectivas jurisdições e recorrer ante os tribunais competentes para dirimir suas diferenças. Neste caso, a parte devedora não poderá suspender os pagamentos nem a credora negar-se a

14 5. Para la calificación de imprevisibilidad de la carga onerosa sobrevenida para una de las prestaciones del contrato, no es necesario atenerse únicamente a los casos de guerra o catástrofes similares, pues es extraordinario y no posible de prever un acto de política económica gubernamental que desencaje con violencia y estrepitosamente la previsible y corriente depreciación monetaria.[...]10. La cláusula sobre invariabilidad de precios entra en el campo de la autonomía de la voluntad, pero sólo comprende lo previsible en materia de precios; la alteración anormal excede el campo contractual y pasa a integrar el terreno de lo heteronómico. (tradução nossa). Cámara Nacional Civil. Sala C. Aycor S.A. c/ Parrone, Atilio y otra - Adquisición de una unidad horizontal a construir. Julgado: 9 maio 1977. E.D. 75-335. 
recebê-los. 0 Poder Executivo nacional fica facultado a ditar disposições explicativas e regulamentares sobre situações específicas, sustentadas na doutrina do artigo 1198 do Código Civil e o princípio do esforço compartilhado. ${ }^{15}$

Na aplicação deste último dispositivo, foi decidido que:

A modificação do sistema monetário disposta pelas autoridades nacionais fundada na emergência econômica repercutiu diretamente em aspectos essenciais da relação contratual sem que se verifique culpa de nenhum dos contratantes, por isso se julga equitativo, em ordem ao princípio do esforço compartilhado, dispor a distribuição igualitária do sacrifício que deverão suportar as partes. A circunstância de que as partes tenham renunciado à teoria da imprevisão e que manifestassem que conheciam a índole e alcance dos compromissos contraídos não é óbice para que suportem em igual medida o prejuízo conduzido pela modificação do sistema monetário disposta pelas autoridades nacionais, pois a relação contratual não pode permanecer alheia às graves consequências da crise que originou a emergência, principalmente se o executado cumpriu com sua obrigação até o mês de janeiro de 2002, quando começou a reger a nova normativa impugnada. ${ }^{16}$

Desse modo, na própria Lei de Emergência e com embasamento no art. 1198 do Código Civil, deu-se entrada à materialização do princípio através da teoria do esforço compartilhado, segundo a qual ambas as partes vêm-se afetadas e devem suportar conjuntamente os embates da economia sobre o equilíbrio do

15 “2) las partes negociarán la reestructuración de sus obligaciones recíprocas, procurando compartir de modo equitativo los efectos de la modificación de la relación de cambio que resulte de la aplicación de lo dispuesto en el artículo $2^{\circ}$ de la presente ley, durante un plazo no mayor a CIENTO OCHENTA (180) días. Acordadas las nuevas condiciones, se compensarán las diferencias que, eventualmente, existan entre los pagos dados a cuenta y los valores definitivamente acordados; 3 ) de no mediar acuerdo entre las partes, las mismas quedan facultadas para seguir los procedimientos de mediación vigentes en las respectivas jurisdicciones y ocurrir ante los tribunales competentes para dirimir sus diferencias. En este caso, la parte deudora no podrá suspender los pagos a cuenta ni la acreedora negarse a recibirlos. El Poder Ejecutivo nacional queda facultado a dictar disposiciones aclaratorias y reglamentarias sobre situaciones específicas, sustentadas en la doctrina del artículo 1198 del Código Civil y el principio del esfuerzo compartido" (tradução e destaque nosso).

${ }^{16}$ "La modificación del sistema monetario dispuesta por las autoridades nacionales fundada en la emergencia económica, repercutió directamente en aspectos esenciales de la relación contractual sin que se verifique culpa de ninguno de los contratantes, por ello se juzga equitativo, en orden al principio del esfuerzo compartido, disponer la distribución igualitaria del sacrificio que deberán soportar las partes La circunstancia de que las partes hayan renunciado a la teoría de la imprevisión y que manifestaran que conocían la índole y alcance de los compromisos contraídos no es óbice para que soporten en igual medida el perjuicio acarreado por la modificación del sistema monetario dispuesta por las autoridades nacionales, pues la relación contractual no puede permanecer ajena a las graves consecuencias de la crisis que originó la emergencia, máxime si el ejecutado cumplió con su obligación hasta el mes de enero de 2002, cuando comenzó a regir la nueva normativa impugnada" (tradução e destaque nosso). Cámara Nacional Civil. Sala B. "Aiani, María c. Kovacs o Kovacs y Bors Alejandro R." Julgado: 23 jun. JA 2003 -III- 648. 
contrato. Esse desprendimento da teoria da imprevisão seria desenvolvido pela Corte Suprema de Justiça da Nação Argentina ao julgar contratos hipotecários afetados pela desvalorização (HAUSER, 2007).

Havendo-se admitido a plena vigência do princípio em matéria de direito interno argentino, cabe verificar a consagração da teoria da imprevisão no direito internacional.

\subsection{A TEORIA DA IMPREVISÃO NO DIREITO INTERNACIONAL}

No campo do Direito Internacional Público, a máxima pacta sunt servanda verifica-se morigerada também pela teoria. $O$ primeiro caso que apresentaria a cláusula rebus sic stantibus como princípio foi a respeito da neutralidade do Mar Negro, em 1870 (ABELLO GALVIS, 2006. p. 209). Já durante o século XX, tanto a Corte Permanente de Justiça Internacional quanto a Corte Internacional de Justiça teriam oportunidade de discorrer sobre o princípio ${ }^{17}$. A própria Convenção de Viena de direito dos tratados estabelece as condições que devem dar-se para ela tornar-se operativa, prescrevendo no seu artigo 62 que:

1. Uma mudança fundamental de circunstâncias, ocorrida em relação às existentes no momento da conclusão de um tratado, e não prevista pelas partes, não pode ser invocada como causa para extinguir um tratado ou dele retirar-se, salvo se: a) a existência dessas circunstâncias tiver constituído uma condição essencial do consentimento das partes em obrigarem-se pelo tratado; e b) essa mudança tiver por efeito a modificação radical do alcance das obrigações ainda pendentes de cumprimento em virtude do tratado.

2. Uma mudança fundamental de circunstâncias não pode ser invocada pela parte como causa para extinguir um tratado ou dele retirar-se: a) se o tratado estabelecer limites; ou b) se a mudança fundamental resultar de violação, pela parte que a invoca, seja de uma obrigação decorrente do tratado, seja de qualquer outra obrigação internacional em relação a qualquer outra parte no tratado.

3. Se, nos termos dos parágrafos anteriores, uma parte pode invocar uma mudança fundamental de circunstâncias como causa para extinguir um tratado ou dele retirar-se, pode também invocá-la como causa para suspender a execução do tratado (BRASIL, 2013).

${ }^{17}$ Dentre os casos da primeira Corte se encontram os "Decretos de nacionalidade em Tunísia e Marrocos" (Grã Bretanha c. Francia); "Tratado de Neuilly" (Grécia c. Bulgária); "Tratado Sino-Belga" (China vs. Bélgica); "Zonas francas” (França vs. Suíça). Já para na atual Corte Internacional, o princípio foi aplicado no "Caso relativo à jurisdição em matéria de pesca (Reino Unido de Grã Bretanha e Irlanda do Norte c. Islândia) e Caso relativo ao Proyecto Gabčíkovo-Nagymaros (Hungria c. Eslováquia)" (ABELLO GALVIS, 2006, p. 213 e ss). 
Mazzuoli destaca o cuidado com que foi inserida essa cláusula na Convenção de Viena, já que a facilidade com que se justificam as circunstâncias na vida internacional poderia dar lugar a práticas abusivas por parte dos Estados com maior força política, para ver-se desobrigados internacionalmente dos compromissos assumidos. Da leitura do dispositivo, pode observar-se que ele exige que: que a circunstância existente ao tempo de conclusão do tratado tenha sido fundamental e não simplesmente um detalhe; que a mudança não tenha sido prevista pelas partes; que as circunstâncias tenham constituído a base essencial para o consentimento das partes em obrigarem-se; que as mudanças ocorridas transformem radicalmente a obrigação de uma das partes onerando-a excessivamente; e que a mudança nas circunstancias se refira a obrigações futuras, e não àquelas já realizadas (MAZZUOLI, 2007, p. 217).

Um caso em que tratou-se da aplicabilidade do artigo 62 da Convenção foi no já citado caso Gabčíkvo-Nagymaros Project (Hungria c. Eslováquia), da Corte Internacional de Justiça. Na decisão, o tribunal entendeu que:

A situação política prevalecente era certamente relevante para a conclusão do Tratado de 1977. Mas o Tribunal recorda que o Tratado previa um programa de investimento conjunto para a produção de energia, o controle de enchentes e melhoria da navegação no Danúbio. Na opinião do Tribunal, as condições políticas prevalecentes assim não eram tão intimamente ligadas ao objeto e propósito do Tratado que constituísse uma base essencial do consentimento das partes e, diante da mudança, alterasse radicalmente o alcance das obrigações a serem executadas. $\mathrm{O}$ mesmo vale para o sistema econômico em vigor no momento da assinatura do Tratado de 1977.

\section{$[\cdots]$}

As novas circunstâncias apresentadas pela Hungria não são, na opinião do Tribunal, de tal natureza, individual ou coletivamente, para que seu efeito fosse capaz de transformar radicalmente o alcance das obrigações a serem executadas para dar cumprimento ao projeto. Uma mudança fundamental de circunstâncias deve ter sido imprevista; a existência das circunstâncias no momento da conclusão do Tratado deve ter constituído uma base essencial do consentimento das partes a ser vinculado pelo tratado. A formulação negativa e condicional do artigo 62 da Convenção de Viena sobre o Direito dos Tratados é uma indicação clara de que a estabilidade das relações convencionais exige que o embasamento de uma mudança fundamental de circunstâncias seja aplicado apenas em casos excepcionais ${ }^{18}$ (ICJ, 1997, p. 63-65).

18 "The prevailing political situation was certainly relevant for the conclusion of the 1977 Treaty. But the Court will recall that the Treaty provided for a joint investment programme for the production of energy, the control of floods and the improvement of navigation on the Danube. In the Court's view, the prevalent political conditions were thus not so closely linked to the object and purpose of the Treaty that they constituted an essential basis of the consent of the parties and, in changing, radically altered the extent of the obligations still to be 
No âmbito interno, aponta-se a diferença entre o sistemas de common law e civil law na aplicação da teoria. Nos países da common law não existe, a diferença do desenvolvimento que teve nos países de tradição civilista, a cláusula rebus sic stantibus como algo imanente ao contrato. Por isso a importância do uso da cláusula escrita neste. No caso dos países de civil law, a lei já prevê a possibilidade de reajustar o equilíbrio recorrendo aos tribunais e invocando dispositivos legais (FUCCI, 2006, p. 1-2), como foi observado no art. 11 da Lei de Emergência Econômica argentina.

No que respeita aos contratos internacionais, os princípios da UNIDROIT também estabelecem contornos precisos para delimitar a possibilidade da alegação da teoria da imprevisão. Esses princípios são particularmente importantes, pois buscam reconciliar ambos os sistemas legais (civil law e common law) (FUCCI, 2006, p. 6).

Depois de definir que os contratos devem ser cumpridos ainda em caso de que estes se tornem mais onerosos, define o hardship, isto é, a excessiva onerosidade:

Artigo 6.2.2 (Definição de hardship) Existe hardship quando ocorrem eventos que alteram substancialmente o equilíbrio do contrato, seja pelo aumento do custo da execução da prestação de uma das partes ou pela diminuição do valor da contraprestação, e (a) os eventos ocorrem ou se tornam conhecidos pela parte em desvantagem após a conclusão do contrato; (b) os eventos não puderem ser razoavelmente levados em consideração pela parte em desvantagem no momento da conclusão do contrato; (c) os eventos estão fora do controle da parte em desvantagem; e (d) o risco de tais eventos não foi assumido pela parte em desvantagem. (UNIDROIT, 2013).

Gama Jr. entende que o reconhecimento do hardship, dentro dos Princípios da UNIDROIT, deu novo impulso à sua aplicação nos contratos de comércio internacional, pois antes a jurisprudência o reconhecia como parte integrante da lex mercatória sob denominação "rebus sic stantibus", mas não exprimia a regra de forma genérica e imprecisa (GAMA JR, 2006, p. 365-366).

performed. The same holds good for the economic system in force at the time of the conclusion of the 1977 Treaty. [...] The changed circumstances advanced by Hungary are, in the Court's view, not of such a nature, either individually or collectively, that their effect would radically transform the extent of the obligations still to be performed in order to accomplish the Project. A fundamental change of circumstances must have been unforeseen; the existence of the circumstances at the time of the Treaty's conclusion must have constituted an essential basis of the consent of the parties to be bound by the Treaty. The negative and conditional wording of Article 62 of the Vienna Convention on the Law of Treaties is a clear indication moreover that the stability of treaty relations requires that the plea of fundamental change of circumstances be applied only in exceptional cases" (tradução nossa). 
Dessa forma, observa-se que a alegação da teoria da imprevisão no direito internacional apresenta-se com contornos definidos, entendendo-se dar lugar à revisão do pactuado quando se trate de circunstâncias intimamente relacionadas ao pactuado, de forma que os eventos decorrentes devam ser interpretados de forma restritiva.

No caso em exame, a Argentina alegou a aplicação da teoria da imprevisão com vistas a justificar o seu descumprimento (parágrafos 221 a 227 do Laudo Arbitral). $O$ tribunal rejeitará a possibilidade da aplicação com base no célebre caso Gaz de Bordeaux (FRANÇA, 2013), resolvido pelo Conselho de Estado francês em 1916.

O referido caso teve lugar pela excessiva onerosidade que uma empresa enfrentou para cumprir suas obrigações de fornecer gás e eletricidade, previstos nos contratos de fornecimento celebrados antes da Primeira Guerra Mundial. Deflagrado o conflito, o preço desses do carvão utilizado pela empresa triplicou tornando-se excessivamente onerosa a sua prestação. $O$ Conselho entendeu:

\begin{abstract}
Assim como a empresa não pode argumentar que ela não deve ser obrigada a suportar qualquer aumento no preço do carvão além de 28 francos por tonelada, valor que, segundo ela, era visto como correspondente ao preço máximo de gás no mercado, seria totalmente excessivo se se admitisse que tais aumentos sejam considerados um risco empresarial normal; pelo contrário, é necessário encontrar uma solução que ponha fim às dificuldades temporárias, tendo em conta tanto o interesse geral,que requer a continuidade do serviço pela empresa utilizando todos os meios de produção,com as condições especiais que não permitem que o contrato possa operar normalmente. Pra isso é necessário decidir, por um lado, que a Empresa é obrigada a fornecer o serviço de concessão e, por outro lado, que durante este período ele deve ter apenas que parte dos efeitos adversos que uma interpretação razoável do contrato permite ${ }^{19}$.
\end{abstract}

${ }^{19}$ Considérant qu'il résulte de ce qui précède que si c'est à tort que la compagnie prétend ne pouvoir être tenue de supporter aucune augmentation du prix du charbon au-delà de 28 francs la tonne, ce chiffre ayant, d'après elle, été envisagé comme correspondant au prix maximum du gaz prévu au marché, il serait tout à fait excessif d'admettre qu'il y a lieu à l'application pure et simple du cahier des charges comme si l'on se trouvait en présence d'un aléa ordinaire de l'entreprise ; qu'il importe au contraire, de rechercher pour mettre fin à des difficultés temporaires, une solution qui tienne compte tout à la fois de l'intérêt général, lequel exige la continuation du service par la compagnie à l'aide de tous ses moyens de production, et des conditions spéciales qui ne permettent pas au contrat de recevoir son application normale. Qu'à cet effet, il convient de décider, d'une part, que la compagnie est tenue d'assurer le service concédé et, d'autre part, qu'elle doit supporter seulement au cours de cette période transitoire, la part des conséquences onéreuses de la situation de force majeure ci-dessus rappelée que l'interprétation raisonnable du contrat permet de laisser à sa charge" (tradução nossa). 
Dessa forma, o Conselho de Estado decidiu que a cidade de Bordeaux devia pagar uma compensação à empresa a ser fixada de comum acordo. Em caso de não o alcançar, o juiz o fixaria.

A partir desse caso, não se tem dúvida acerca da aplicabilidade da teoria para os contratos de concessão de um modo geral, desde que dadas as condições delineadas pelo antigo precedente: o acontecimento devia ser imprevisível e estranho às partes, superar todas as expectativas razoáveis e alterar profundamente o equilíbrio do contrato.

Diferentemente, o Tribunal Arbitral do caso CMS-ARG entendeu que não se davam, no caso concreto, os supostos para a aplicação da teoria da imprevisão da forma que o fizera o Conselho de Estado francês.

Precisamente, o Tribunal entendeu que o desequilíbrio foi previsto. Afirma categoricamente que:

Neste plano, o Demandante, ao argumentar que se ofereceram garantias expressas para evitar o risco de desvalorização, também pensa que esse risco em efeito se previu. Em segundo lugar, a teoria da imprevisão requer que a parte prejudicada solicite a rescisão do contrato perante um tribunal competente, em tanto que no presente caso a medida foi decidida unilateralmente por uma parte. Por outra parte, como já se destacou, os tribunais sustentaram opiniões mas bem críticas a respeito das medidas adotadas. Em essência, o sistema de pesificación foi imposto e não se cumpriu tampouco o objetivo de restabelecer o equilíbrio e indenizar as diferenças dentro de um prazo de 180 dias $^{20}$ (parágrafo 225 do Laudo Arbitral).

O principal argumento para a rejeição da teoria diz respeito à previsibilidade. Não foi, como no caso Gaz de Bordeaux, um evento externo (a guerra), mas uma circunstância para a qual o contrato se encontraria preparado. Precisamente, os valores a serem calculados em dólares, com coeficientes externos de correção e estabilização, teriam sido a nota de previsibilidade que o investidor teve para realizar o investimento. A paridade cambial da Ley de Convertibilidad com o tempo resultaria insustentável.

Cabe perguntar-se, então, se não deveria ter-se dado lugar à teoria do esforço compartilhado nos casos de contratos de investimento, aplicada para os casos

20 "En este plano, el Demandante, al argumentar que se ofrecieron garantías expresas para evitar el riesgo de devaluación, también piensa que ese riesgo en efecto se previó. En segundo lugar, la teoría de la imprevisión requiere que la parte perjudicada solicite la rescisión del contrato ante un tribunal competente, en tanto que en el presente caso la medida fue decidida unilateralmente por una parte. Por otra parte, como ya se señaló, los tribunales han sostenido opiniones más bien críticas acerca de las medidas adoptadas. En esencia, el sistema de pesificación fue impuesto y no se cumplió tampoco el objetivo de restablecer el equilibrio e indemnizar las diferencias dentro de un plazo de 180 días" (tradução nossa). 
internos, sobretudo aos de financiamento de imóveis. Embora a crise econômica tenha sido levada em conta para considerar o montante da indenização, não foi no sentido de dividir o prejuízo, mas no sentido de restar do valor indenizável as perdas que a CMS teria sofrido de qualquer forma em virtude da retração do consumo (parágrafos 442 a 448 do Laudo Arbitral).

Um elemento a considerar é quão grande precisa ser uma crise econômica como para servir de pressuposto à teoria. Neste ponto, o Tribunal não chega a se espraiar em argumentos, bem como também não diz nada a respeito da contribuição para a crise por parte de quem alega a situação de onerosidade. Trata-se de dois elementos que se constituiriam em verdadeiros pântanos de discussão acerca de política econômica. Como diferenciar diante de uma economia globalizada, de feições complexas, quando uma crise econômica é provocada por motivos externos ou internos? Na verdade tentar a empreitada de discutir relações de causalidade nesse nível torna-se uma tarefa titânica que estará longe de obter respostas jurídicas.

O Tribunal condenou a República Argentina ao pagamento de 133,2 milhões de dólares em conceito de indenização em favor da CMS.

\section{CONSIDERAÇÕES FINAIS}

O caso apresentado é apenas um dos tantos em que o país foi levado ao sistema do CIRDI em virtude do processo de privatizações. Como se observou, nesses anos o paradigma de rule-of-law preconizado foi a previsibilidade, a intangibilidade dos contratos, as garantias ao investimento, como uma forma de blindagem fictícia ao cenário geral. A implantação do modelo nos países da América Latina teve sérias consequências socioeconômicas, que não poderiam ter sido desconsideradas pelo Tribunal na hora de julgar.

A globalização da economia aumenta a incerteza nos contratos internacionais, aumenta a insegurança econômica e jurídica. Realmente, na economia globalizada os fatores de risco ganham maior peso, pois o elemento concorrencial se intensifica, e a velocidade dos eventos supera a capacidade de governos e indivíduos de reagir adequadamente face às ameaças. A situação se agrava se se trata de contratos de investimento, em democracias jovens e com governos que não apresentam uma continuidade de projeto de desenvolvimento após as eleições dos seus mandatários. Os contratos de investimentos representam um desafio à divisão do publico e do privado na ordem econômica globalizada, tanto no que diz respeito aos atores envolvidos, de onde se deve buscar resposta 
aos conflitos e quem deve adotar essas decisões. Como se viu, as respostas da jurisprudência interna resultaram diferentes ao entendimento do Tribunal no caso ora analisado.

A Argentina não conseguiu enquadrar-se nos requisitos da aplicação da regra segundo consta nos instrumentos internacionais, basicamente ao entender-se que faltou a ela o elemento da imprevisibilidade. Mas os questionamentos persistem. Era possível prever a crise? Sabia o país o que estava por vir nos próximos dez anos?

Entende-se que hoje a teoria da imprevisão deve servir de ferramenta adequada para equilibrar as consequências negativas das crises econômicas que não podem ser circunscritas a determinado território, mas se tornam globais. Hoje não é possível definir se a crise na Espanha é totalmente causada pela crise do subprime americano e quanta é a responsabilidade do país em tornar-se terreno fértil para a crise. Os mesmos problemas se repetem em outras partes do mundo.

A rule-of-law, como modelo de desenvolvimento neoliberal, hoje deve dar lugar a mecanismos de experimentação, mensuração, não baseados em fórmulas matemáticas prontas, mas em mecanismos que levem em conta o contexto. Isso restou evidente na crise vivenciada em 2001 na Argentina. Falta saber como teria sido uma decisão do tribunal citado baseada em parâmetros mais abertos e receptivos ao meio em que tais circunstâncias se deram.

A teoria da imprevisão, embora positivada com pressupostos de aplicação precisos, requererá uma apurada análise das condições fáticas, haja vista a complexidade das novas circunstâncias que afetam a execução dos contratos, quer sejam internos, quer sejam internacionais.

\section{REFERÊNCIAS}

ABELES, Martín. El proceso de privatizaciones en la Argentina de los noventa: ¿reforma estructural o consolidación hegemónica? Época, ano 1. n. 1, 1999.

ABELLO GALVIS, Ricardo. De la cláusula rebus sic stantibus al cambio fundamental en las circunstancias. Derecho Internacional Contemporáneo. In: ABELLO GALVIS, Ricardo (Org.). Derecho Internacional contemporáneo. Liber Amicorum en homenaje a Germán Cavelier. Bogotá: Ed. Universidad del Rosario, 2006.

ALTERINI, Atilio Aníbal (Org.). El derecho privado ante la internacionalidad, la integración y la globalización. Homenaje al profesor Miguel Angel Ciuro Caldani. Buenos Aires: La Ley, 2005.

ALTERINI, Atílio A.; AMEAL, Oscar J.; LOPEZ CABANA, Roberto M. Derecho de obligaciones: civiles y comerciales. 2. ed. atual. Buenos Aires: Abeledo-Perrot, 2003.

AMATO. El fantasma aterrador del Rodrigazo. Clarín, 9 mar. 2013. Disponível em: <http:// www.clarin.com/opinion/fantasma-aterrador-Rodrigazo_0_8627138 18.html>. Acesso em: 22 jul. 2013. 
ARAUJO, Nádia. Contratos internacionais: autonomia da vontade, Mercosul e Convenções Internacionais. 3. ed. Rio de Janeiro: Renovar, 2004.

ARGENTINA. Cámara Nacional Civil. Sala C. Aycor S.A. c/ Parrone, Atilio y otra - Adquisición de una unidad horizontal a construir. Julgado: 9 maio 1977. E.D. 75-335.

. Cámara Nacional Civil. Sala B. "Aiani, María c. Kovacs o Kovacs y Bors Alejandro R." julgado em 23 jun. JA 2003-III-648.

Cámara Nacional Civil Cámara Nacional Civil, sala C, "Cabal, Justo I. c/ Madero, Miguel y otro", julgado em 18 nov 1953, La Ley, Tomo 75, p. 255-263.

. Cámara Nacional Civil, sala D, "Sola, Félix c/ Colonias y Estancias El Rodeo S.A.", julgado em 26 maio 1964, El Derecho, Tomo 10, p. 726-732.

. Cámara Nacional Civil, sala F, “Pantaleón, Horacio J. c/ Carnerero, Ángel V.”, julgado em 2 abr. 1965, El Derecho, Tomo 12, p. 89-97.

Cámara Nacional Civil., sala D, "Reyes, Juan C., suc. c/ Bronstein, José V. y otros", julgado em 30 dec. 1965, El Derecho, Tomo 14, págs. 100-104.

Cámara Nacional Civil, sala E, "La Hidrófila Argentina, S.A.C.I. c/ Municipalidad de la Capital", julgado em 1 mar. 1966, El Derecho, Tomo 14, p. 160-167.

Cámara Nacional Federal, Sala Civil y Com., "Oks Hnos. y Cía., S.A. c/ Gobierno Municipal", julgado em 25 ago 1965. El Derecho, Tomo 14, p. 170-177.

- Corte Suprema de Justiça da Nação. Rinaldi, Francisco Augusto y otros c/ Guzmán Toledo, Ronal Constante y otro s/ Ejecución hipotecaria. Julgado em: 15 mar. 2007. La ley, $2007-\mathrm{B}, 415$.

. Código Civil de la Nación. Disponível em: <http:/www.infoleg.gov.ar /infolegInternet/ anexos/ 105000 109999/109481/texact .htm>. Acesso em: 12 jul. 2013.

. Ley 23.696 de Reforma del Estado. Disponível em: <http://infoleg. mecon.gov.ar/ infolegInternet/anexos/0-499 9/98/norma.htm>. Acesso em: 22 jul. 2013.

- Ley de Emergencia Pública y de Reforma del Régimen Cambiario. Ministério de Economia. Disponível em: <http://www.mecon.gov.ar/digesto/leyes/ley25561.htm>. Acesso em: 22 jul. 2013.

Tratado entre la República Argentina y los Estados Unidos de América sobre Promoción y Protección Recíproca De Inversiones. Disponível em: <http://infoleg.mecon.gov. ar/infolegInternet/anexos/0-4999/523/norma.htm>. Acesso em: 20 jul. 2013.

BLANCO, Vicente D. El primer Laudo Arbitral en el CIADI "sobre el fondo" relativo a la crisis argentina 2000-2002: El laudo de mayo de 2005 en el caso "CMS Gas Transmission Company c. República Argentina" (Trato justo y equitativo, cumplimiento de los compromisos con la inversión extranjera y estado de necesidad en la crisis argentina). In: ALTERINI, Atilio Aníbal (Org.). El derecho privado ante la internacionalidad, la integración y la globalización. Homenaje al profesor Miguel Angel Ciuro Caldani. Buenos Aires: La Ley, 2005.

BRASIL. Convenção de Viena sobre Direito dos Tratados. Planalto. Disponível em: <http:// www.planalto.gov.br/ccivil_03/_Ato2007-2010/2009/Decreto/D7030.htm>. Acesso em: 22 jul. 2013.

CASTRO, Jorge, Política y Economía en la Argentina de los 90. La Política Económica de una sociedad en conflicto. Visiting resource professor paper. LLILAS Austin: University of Texas at Austin, 2001. Disponível em: <http://lanic.utexas.edu/project/etext/llilas/vrp/castro.pdf>. Acesso em: 22 jul. 2013. 
CORNET, Manuel. La aplicación de la teoría de la imprevisión y la emergencia económica. Anuário de Derecho Civil. t. VII. Córdoba: Universidad Católica de Córdoba, 2002.

CORTES CONDE, Roberto. La crisis argentina 2001-2002. Cuadernos de Economía, v. 40, n. 121, 2003. Disponível em: <http://www.scielo.cl/scielo.php?script=sci_arttext\&pid=S07176 8212003012100049>. Acesso em: 20 jul. 2013.

FELDSTEIN DE CÁRDENAS, Sara L. Arbitraje e inversiones extranjeras. In: ALTERINI, Atilio Aníbal (Org.). El derecho privado ante la internacionalidad, la integración y la globalización. Homenaje al profesor Miguel Angel Ciuro Caldani. Buenos Aires: La Ley, 2005.

FRANÇA. Conselho de Estado. Compagnie Generaled'Eclaitrage de Bordeaux. Rec. 125. Disponível em: <http://www.legifrance.gouv.fr/affichJuriAdmin.do?idTexte=CETATEXT000 007629465\&date Texte=>. Acesso em: 25 jul. 2013.

FONSECA, Karla C. Investimentos estrangeiros: regulamentação internacional e acordos bilaterais. Curtiba: Juruá, 2008.

FUCCI, Frederick. Hardship and changed circumstances as grounds for adjustment or nonperformance of contracts: practical considerations in international infrastructure investment and finance, presentation at Spring Meeting (April 2006). American Bar Association, Section of International Law. Disponível em: <http:// www.cisg.law.pace.edu/cisg/biblio/fucci.html>. Acesso em: 30 jul. 2013.

GAMA JR, Lauro. Contratos Internacionais à luz dos princípios da UNIDROIT 2004. Soft law, arbitragem e jurisdição. Rio de Janeiro: Renovar, 2006.

HAUSER, Irina. Para la Corte, nada mejor que el esfuerzo compartido. Página 12, 16 mar. 2007. Disponível em: <http://www.paginal2.com.ar/diario/economia/2-81835-2007-03-16. html>. Acesso em: 23 jul. 2013.

ICSID. ICSID Convention, Regulationsand Rules. Disponível em: https://icsid.worldbank.org/ ICSID/ICSID/ RulesMain.jsp>. Acesso em: 22 jul. 2013.

International Centre for Settlement on Investement Disputes. Disponível em: <https:// icsid.worldbank.org/ICSID/FrontServlet>. Acesso em: 22 jul. 2013.

CMS Gas Transmission Company v. Argentine Republic (ICSID Case n. ARB/01/8). Disponível em: <https://icsid.worldbank.org/ICSID/FrontServlet? requestType=CasesRH\& actionVal=showDoc\&docId=DC504_Sp\&caseId=C4>. Acesso em: 12 jul. 2013.

ICJ. Gabčíkovo-Nagymaros project (Hungary - Islovakia). Julgado em 25 set. 1997. ICJ Reports 1997. p. 7. Disponível em: < http://www.icj-cij.org/docket/files/92/7375.pdf>. Acesso em: 20 jul. 2013.

JIMENEZ GIL, William. La teoria de laimprevisión ¿Regla o principio? Misión Jurídica Universidad, v.2 t. 2 Bogotá: Colegiomayor de Cundinamarca, 2010.

KLOR, Adriana Dreyzin de; FERNANDEZ ARROYO, Diego P.; PIMENTEL, Luiz O. Investimento estrangeiro. DeCITA - Direito do Comércio Internacional - Temas e atualidades. Florianópolis: Fundação Boiteux, 2005.

LALIVE, Pierre. Contrats entre Etats et presonnes privées. Recueil des Cours. t. III, 5-240. TheHague: TheHagueAcademy of International Law, 1969.

LORENZETTI, Ricardo L. El problema de la previsibilidad en la regla contractual como incentivo a las inversiones. In: KLOR, Adriana Dreyzin de; FERNANDEZ ARROYO, Diego P.; PIMENTEL, Luiz O. Investimento estrangeiro. DeCITA - Direito do Comércio Internacional - Temas e atualidades. Florianópolis: Fundação Boiteux, 2005. 
MAGOJA, Eduardo E. La teoría de la imprevisión: el gobierno de la equidad en la ejecución de los contratos. Prudentia Iuris, n. 74. 2012. p. 233. Disponível em: <http://bibliotecadigital.uca. edu.ar/ repositorio/revistas/teoria-imprevision-gobierno-equidad-contratos.pdf. Acesso em: 25 jul. 2013.

MAZZUOLI, Valério de Oliveira. Curso de Direito Internacional Público. 3. ed. São Paulo: Revista dos Tribunais, 2006.

ONU. Assembleia Geral (XXI). Resolução 1803. Disponível em: <http://www2.ohchr.org/ Spanish /law/recursos.htm>. Acesso em: 22 jul. 2013.

Assembleia Geral (XXV). Resolução 2.626. Disponível em: <http://daccess-dds-ny. un.org/doc/RESOLUTION/GEN/NR0/348/91/IMG/NR034891.pdf?OpenElement>. Acesso em: 22 jul. 2013.

ORGAZ, Alfredo. El contrato y la doctrina de la imprevisión. La Ley, t. 60. Buenos Aires: Abeledo Perrot, 1950.

ORREGO VICUÑA, Francisco. De los contratos y tratados en el mercado mundial. In: KLOR, Adriana Dreyzin de; FERNANDEZ ARROYO, Diego P.; PIMENTEL, Luiz O. Investimento estrangeiro. DeCITA - Direito do Comércio Internacional - Temas e atualidades. Florianópolis: Fundação Boiteux, 2005.

REZEK, Francisco. Direito Internacional Público: curso elementar. 10. ed. São Paulo: Saraiva, 2006.

REZZONICO, Juan C. Principios fundamentales de los contratos. Buenos Aires: Astrea: 1999.

PALLARÉS, Beatriz. Reflexiones acerca del consentimento del Estado para someterse al arbitraje. In: KLOR, Adriana Dreyzin de; FERNANDEZ ARROYO, Diego P.; PIMENTEL, Luiz O. Investimento estrangeiro. DeCITA - Direito do Comércio Internacional - Temas e atualidades. Florianópolis: Fundação Boiteux, 2005.

RODRIGUEZ JIMENEZ, Sonia. Los tratados bilaterales de promoción y protección recíproca de inversiones como vía de acceso al CIADI. KLOR, Adriana Dreyzin de; FERNANDEZ ARROYO, Diego P.; PIMENTEL, Luiz O. Investimento estrangeiro. DeCITA - Direito do Comércio Internacional - Temas e atualidades. Florianópolis: Fundação Boiteux, 2005.

SCHLEE, Paula C. Padrões de tratamento do estrangeiro e sua propriedade me matéria de investimento: análise da jurisprudência do ICSID. In: KLOR, Adriana Dreyzin de; FERNANDEZ ARROYO, Diego P.; PIMENTEL, Luiz O. Investimento estrangeiro. DeCITA - Direito do Comércio Internacional - Temas e atualidades. Florianópolis: Fundação Boiteux, 2005.

SHAPIRO, Mario G. Repensando a relação entre Estado, direito e desenvolvimento. Os limites do paradigma Rule of Law e a relevância das alternativas institucionais. In: Estado de Direito e o Desafio do Desenvolvimento. Série Direito em debate. São Paulo: Saraiva, 2011.

SHAPIRO, Mario G.; TRUBEK, David. Redescobrindo o direito e desenvolvimento: experimentalismo, pragmatismo democrático e diálogo horizontal. In: Direito $e$ desenvolvimento: um diálogo entre os BRICS. Série Direito em debate. São Paulo: Saraiva, 2012. STERN, Brigitte. O contencioso dos investimentos internacionais. Série Entender o Mundo. v. 3. Barueri: Manole, 2003.

TRUBEK, David M.; SANTOS, Alvaro (Orgs.); Introduction: The third moment in law and development theory and the emergence of a new critical practice. In: The new law and economic development: a critical appraisal. Cambridge: Cambridge University Press, 2006. 
TRUBEK, David M.; COUTINHO, Diogo R.; Schapiro, Mario; Toward a New Law and Development: New State Activism in Brazil and the Challenge for Legal Institutions. Univ. of Wisconsin Legal Studies Research Paper. n. 1207. Wisconsin: University of Wisconsin, 2012.

UNIDROIT. UNIDROIT Principles of International Commercial Contracts 2010. Disponível em: $<$ http://www.unidroit.org/english/principles/contracts/principles2010/translations/blackletter 2010portuguese.pdf>. Acesso em: 22 jul. 2013.

UNITED NATIONS. Responsibility of States for Internationally Wrongful Acts. Yearbook of the International Law Commission 2001. v. II, part. 2. p. 80. Disponível em: http://untreaty. un.org/ilc/publications/yearbooks/Ybkvolumes(e)/ILC_2001_v2_p2_e.pdf> Acesso em: 20 jul. 2013.

VERDROSS, Alfred. Le fondement du Droit International. Recueil des Cours, v. 1927-1.

ZIMMERMAN, Reinhard. The Law of Obligations: Roman Foundations of the Civilian Tradition. Cambridge: Clarendon Paperbacks, 1995. 